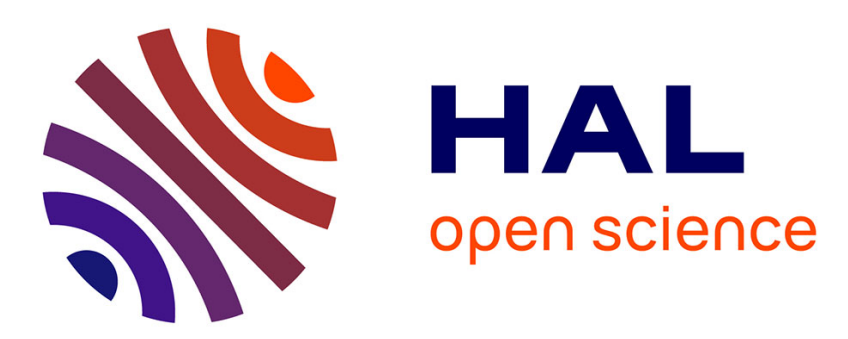

\title{
Racialized landscapes: whiteness and the struggle over farmworker housing in Woodburn, Oregon
}

\author{
Lise Nelson
}

\section{To cite this version:}

Lise Nelson. Racialized landscapes: whiteness and the struggle over farmworker housing in Woodburn, Oregon. cultural geographies, 2008, 15 (1), pp.41-62. 10.1177/1474474007085782 . hal-00572012

\section{HAL Id: hal-00572012 \\ https://hal.science/hal-00572012}

Submitted on 1 Mar 2011

HAL is a multi-disciplinary open access archive for the deposit and dissemination of scientific research documents, whether they are published or not. The documents may come from teaching and research institutions in France or abroad, or from public or private research centers.
L'archive ouverte pluridisciplinaire HAL, est destinée au dépôt et à la diffusion de documents scientifiques de niveau recherche, publiés ou non, émanant des établissements d'enseignement et de recherche français ou étrangers, des laboratoires publics ou privés. 


\title{
Racialized landscapes: whiteness and the struggle over farmworker housing in Woodburn, Oregon
}

\author{
Lise Nelson \\ Department of Geography, University of Oregon
}

\begin{abstract}
Through an analysis of political resistance to the construction of subsidized farmworker housing in Woodburn, Oregon between 1991 and 1996, this article explores the defense of normative whiteness in relation to a largely undocumented Mexican immigrant population residing in the community. It is argued that for many (mostly white) city leaders and residents, the construction of urban farmworker housing represented a racialized and spatial transgression that undermined the normalized geography of farmworker invisibility - the labor camp. While the racial anxieties linked to the permanent settlement of low-wage immigrant workers had percolated for many years, the public debate over farmworker housing represented a moment when the longstanding anxiety of white residents could be publicly articulated, as well as coded and expressed as something other than race. The analysis builds on work in geography examining how spatial metaphors and practices are used to police the borders of whiteness and difference.
\end{abstract}

Keywords: Farmworkers $\bullet$ place $\cdot$ race $\bullet$ whiteness

Whiteness is everywhere in U.S. culture, but it is very hard to see. [...] As the unmarked category against which difference is constructed, whiteness never has to speak its name, never has to acknowledge its role as an organizing principle in social and cultural relations.

George Lipsitz ${ }^{1}$

Cholarship on whiteness, which has exploded over the last 15 years, seeks to make visible $\checkmark$ and examine white privilege by theorizing it as the 'unmarked category' upon which the racialization of non-white difference depends. ${ }^{2}$ While Lipsitz may be correct in some sense that 'whiteness is everywhere,' the contribution of geographers to these debates is to move beyond 'everywhere' and argue that whiteness is produced and reproduced spatially. In other words, whiteness is place-bound and represents a set of ideological and material practices located in time and space. Moreover, spatial configurations are key to its invisibility and normalization. As Audrey Kobayashi and Linda Peake write, 'whiteness is a place from which to look at ourselves and the surrounding society; a position of normalcy, and perhaps moral superiority, from which to construct a landscape of what is same and what is different. ${ }^{3}$ Therefore, mapping whiteness requires attention to the exercise of racialized power in specific places, its production across scale, and particularly the use of space to naturalize white privilege. $^{4}$ 
Through an analysis of political resistance to the construction of subsidized farmworker housing in Woodburn, Oregon between 1991 and 1996, this article explores the defense of normative whiteness in relation to a largely undocumented Mexican immigrant population residing in the community. As I argue, for many (mostly white) city leaders and residents, the construction of urban farmworker housing represented a racialized and spatial transgression that undermined the normalized geography of farmworker invisibility - the labor camp. Given that Latinos represented one-third of the town's population by 1990 and downtown Woodburn was comprised primarily of Mexican- and Mexican-American-owned businesses catering to a largely Spanish-speaking (and a growing number of indigenous language-speaking) clientele (Figure 1), the efforts to stop farmworker housing were largely symbolic. In other words, by 1990 Woodburn's central urban landscapes were already 'spaces of difference' and the denial of a farmworker housing project would not change that reality. Instead, fierce public debate over farmworker housing represented a moment when the longstanding anxiety of white residents could be publicly articulated, as well as coded and expressed as something other than race.

The dynamics of racial coding - particularly the displacement of explicitly racist language onto categories seemingly unrelated to race - has been central to work on whiteness, as well as to critical race theory more broadly. Although racial codes have a long history in the USA, racism became more deeply masked in the wake of the civil rights movement as overtly racist language became unacceptable, at least in the public sphere. ${ }^{5}$ Whiteness, inextricably linked to the construction of racialized others, also became reconfigured in the process. ${ }^{6}$ One of the key challenges for scholarship on whiteness has been to chart this reconfiguration and make visible a category that by its very nature is unmarked - everywhere and nowhere.

Geographers have explored how constructions of space provide a vehicle for racial codes, both for those marked as cultural others (who are 'raced') and those implicitly marked as embodying the cultural norm (assumed to be 'white'). David Delaney points out that geographers' critical engagement of race 'has enriched our general understanding of how space

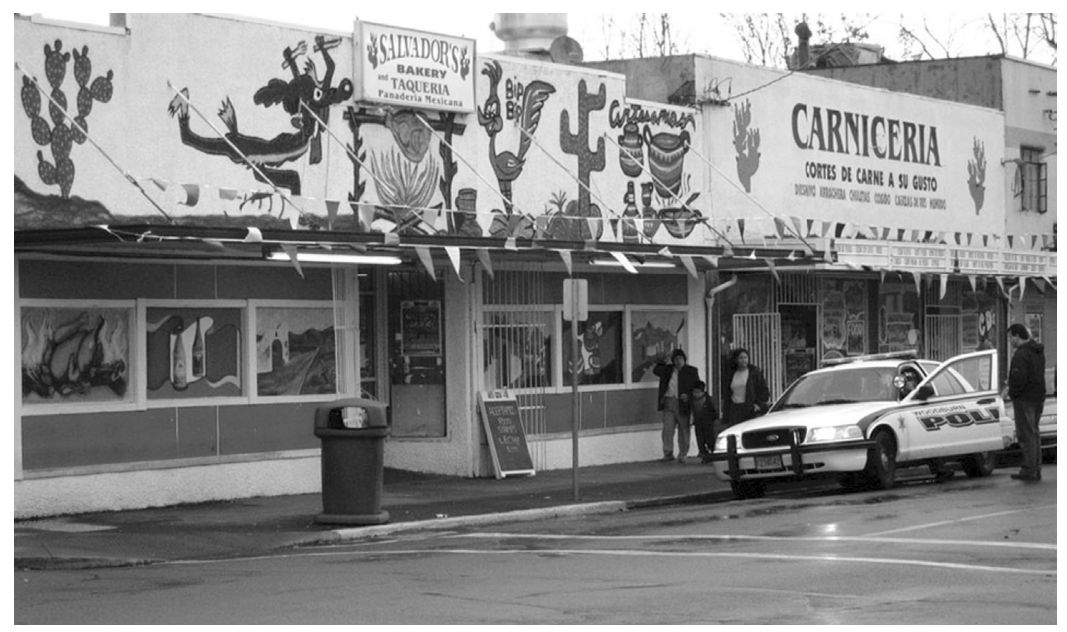

FIGURE 1 Downtown Woodburn, photo taken by author in 2004 . 
works to condition the operation of power and the constitution of relational identities." Adopting this approach, geographers studying whiteness have been particularly interested in how spatial metaphors and practices are used to police the borders of whiteness. For example, in his study of two north London shopping centers, Peter Jackson notes that 'where it was expressed at all whiteness was articulated through a series of other discourses about modernity, neighbourhood change, pollution and domestication. ${ }^{9}$ In a similar vein, James Duncan and Nancy Duncan examine the construction of white privilege through the coding of esthetic landscapes in New York. ${ }^{9}$ Laura Pulido turns her attention to the construction of academic knowledge, exploring how normative whiteness shapes theories of environmental racism. ${ }^{10}$ She critiques the extent to which studies of environmental racism focus on intentionally racist acts rather than larger socio-spatial inequalities that reproduce white privilege. Building on this literature in geography, my analysis examines how race and space inform the narratives deployed to resist farmworker housing in Woodburn.

The town of Woodburn (population 20,100 in 2000) lies at the heart of Oregon's richest agricultural region, the Northern Willamette Valley (see map Figure 2). While the region has been economically reliant on Mexican and Mexican-American farmworkers since the 1940s, until the 1980s most of those workers had been transient in time (migratory workers) and spatially contained (within labor camps). The intensification and diversification of forestry and agriculture in the 1980s increased the demand for rural workers in the region, both in terms of raw numbers and the length of the hiring season. These regional dynamics, in combination with broader political economic changes, facilitated a process through which a growing number of farmworkers began to transition from living in camps to seeking long-term housing in nearby towns, including and particularly in Woodburn. These geo-demographic shifts made the realities and social costs of an extremely low-wage and insecure workforce readily apparent to white residents. ${ }^{11}$ In other words, by the late 1980 s, white residents began to see and experience first-hand the social reproduction of the region's rural workforce, a reality that had, for many decades, largely been contained in the space of the labor camp. Today Woodburn is the largest town in Oregon with a majority Latino/a population. ${ }^{12}$

As more farmworkers began to remain for longer periods or settle permanently during the 1980s, the demand for low-income housing quickly outstripped the supply. ${ }^{13}$ Landlords often took advantage of the situation and crowded multiple immigrant families within single-family homes and apartments. Overcrowding contributed to decaying housing stock in many neighborhoods, unkempt lawns, uncollected garbage, and social tensions more generally. In early 1991, for example, the local weekly newspaper, the Woodburn Independent, reported that fines were levied on a landlord who maintained rental property in which 'rats and other vermin are given free run of the units [...] Floors are rotting away. [...] The windows are hard to open, making it hard to even breathe. ${ }^{14}$ One Latina farmworker I interviewed who lived in a house with four other families in the late 1980s felt that she could not let her children out of the one room they rented in the house because of the fights that broke out in the living room and on the street. ${ }^{15}$ In October 1990 the city council organized a 'Livability Forum,' a meeting that according to the Woodburn Independent was 'inundated with a large crowd of angry citizens. ${ }^{.16}$

Although the consequences of the housing crisis were felt by all residents, I am particularly interested in the ways deteriorating residential landscapes exacerbated on-going racial anxiety on the part of many white residents. While these anxieties had percolated over many years, they 


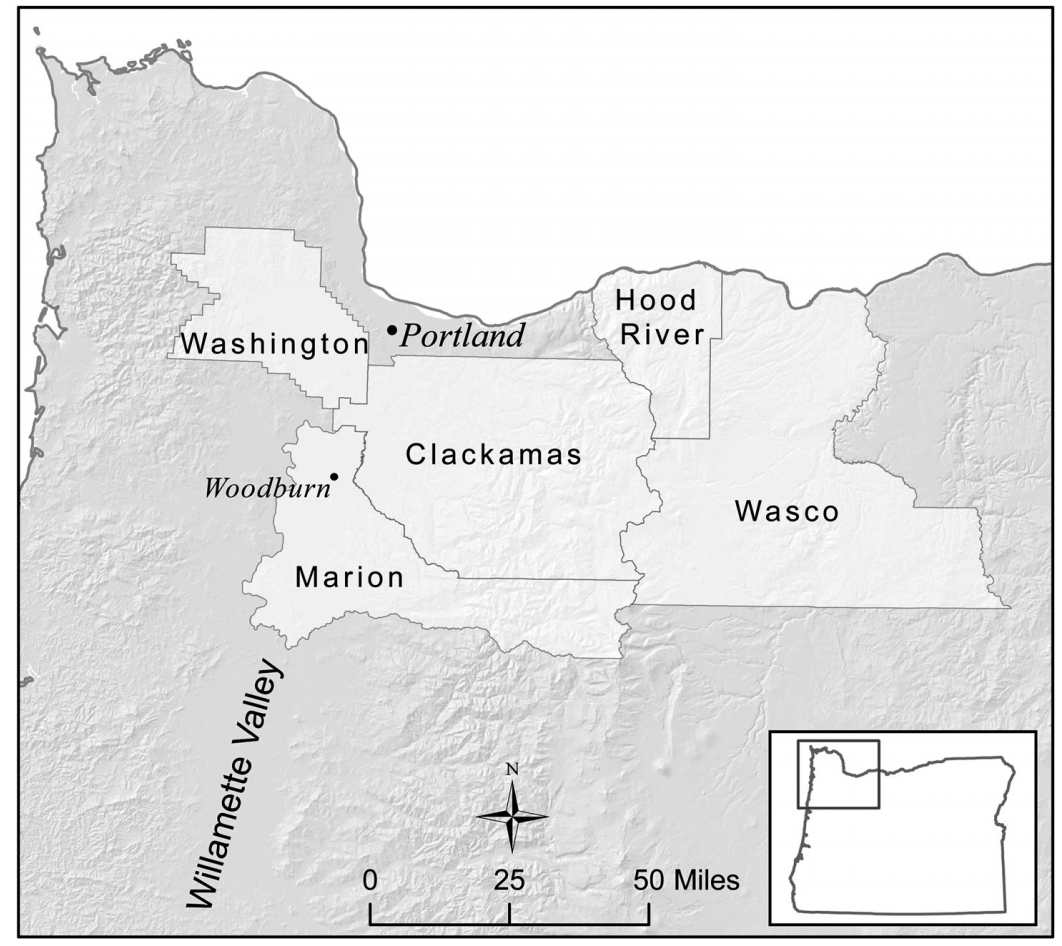

FIGURE 2 Woodburn's and the Northern Willamette Valley of Oregon. Cartography by Maylian Pak and Jacob Bartrufl.

became publicly articulated through two sets of events that I treat as condensation points for understanding shifting constructions of whiteness and place in the community. In 1992, and again in 1996, heated public debates emerged over farmworker housing projects proposed inside the city limits. Both projects were developed by a non-profit organization, the Farmworker Housing Development Corporation (FHDC), a group launched in 1991 by a coalition of Latino farmworker advocacy organizations in the area. Despite the fact that the housing projects would begin to alleviate the community's visible housing crisis, many white residents of Woodburn, and most elected city leaders (also overwhelmingly white), vigorously resisted their construction. The resistance to these projects was both formal and informal, ranging from efforts by the city council to stop the projects to anonymous racist hate mail directed at FHDC. Nevertheless, in the end, FHDC built a 90-unit complex called Nuevo Amanecer (New Dawn) in 1994, and a smaller complex (12 units) called Esperanza Court (Hope Court), completed in 1997 (see map, Figure 3).

To provide a context for the housing crisis that emerged in Woodburn in the 1980s, as well as the establishment of FHDC in 1991, I begin by reviewing the regional political economic forces driving labor immigration to the Northern Willamette Valley. I then analyze struggles over Nuevo Amanecer and Esperanza Court, focusing on the narratives and strategies deployed to resist the two housing projects as a window into the spatial dimensions of white privilege in the community. Although the racialization of space occurs through a myriad 


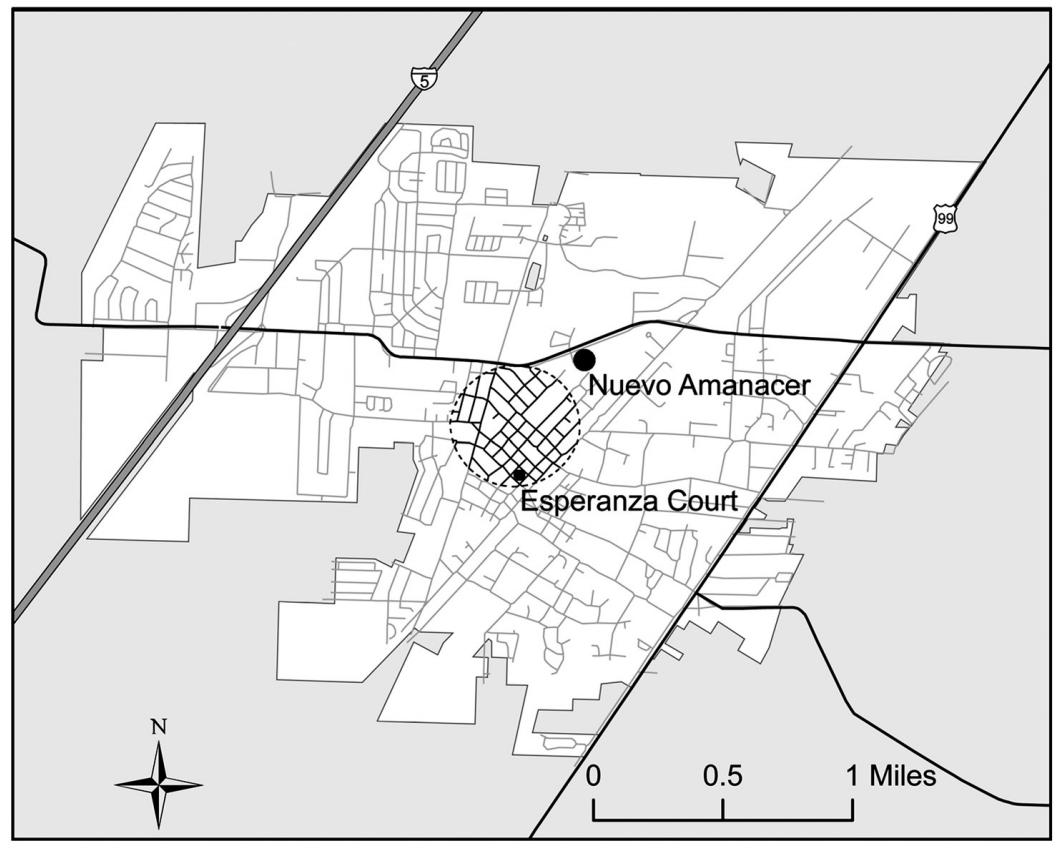

FIGURE 3 City map of Woodburn and the location of Nuevo Amanecer and Esperanza Court. Dashed circle indicates approximate boundaries of 'old' downtown Woodburn. Cartography by Maylian Pak and Jacob Bartrufl.

of daily practices, both conscious and unconscious, the debates that emerged over farmworker housing in Woodburn threw these dynamics into relief and made them quite public. Analysis of city council meetings, newspaper reports and interviews with key actors connected to these struggles reveals the explicit and implicit spatial codings used to demarcate hegemonic whiteness and exclude racially marked (low-wage and 'illegal') bodies from Woodburn's landscapes. ${ }^{17}$ I conclude by discussing how analysis of these local struggles over race and space contributes to scholarship on whiteness in geography.

\section{Political economic contexts and the shifting politics of belonging}

Immigrant farmworkers from Mexico first came in significant numbers to the Northern Willamette Valley during the Bracero Program. According to Ernesto Gamboa, the temporary worker program brought over 47,000 Mexican workers to the region between 1942 and 1947, after which it was largely abandoned by northwest growers. ${ }^{18}$ Despite its brief official impact, however, the program had a lasting effect on the structure and composition of the region's rural labor force, as northwest growers did not return to the white labor force that predominated prior to World War II. First, some Bracero workers, having established a relationship with particular employers, continued to return extra-legally to work in the region. 
Second, and perhaps more importantly in the short term, after 1947 growers in the Pacific Northwest declined to accept Bracero contracts because they were able to recruit MexicanAmerican farmworkers from Texas and other parts of the southwest more cheaply and with fewer regulatory barriers. ${ }^{19}$ In this way, by the late 1940s Mexican and Mexican-American farmworkers, moving between different harvests and between different states, became part of the economic fabric of rural Oregon and other Pacific Northwest states.

The region's growing economic dependence on Mexican and Mexican-American farmworkers in the post-World War II era did not translate into Latino/a bodies 'belonging' socially or politically. ${ }^{20}$ Farmworkers generally passed through Oregon for only weeks or months at a time, and the majority were housed 'on-farm' in labor camps. In his historical geography of farmworkers in California during the first half of the 20th century, Don Mitchell links the highly marginalized position of farmworkers to the 'social and spatial relations of agricultural labor reproduction. ${ }^{21}$ Under this structure not only has farmwork been seasonal and low paid, but the labor camp acted as a key spatial mechanism for containing the social reproduction and visibility of a workforce integral to rural economies. While Mitchell traces the evolution of California's rural landscapes during the first half of the 20th century, the structures he identifies did not mature in Oregon until after World War II.

In addition to reflecting the social and spatial structures of agricultural labor, the persistent invisibility and exclusion of farmworkers in Oregon during this period was linked to entrenched hierarchies of race in the Pacific Northwest. Dominant constructions of regional identity have historically been linked - implicitly and explicitly - to whiteness and the exclusion of difference. For example, although Oregon's 1859 constitution was nominally antislavery, it explicitly sought to exclude blacks and mulattos who had begun to settle in the state. $^{22}$ During the early decades of the 20th century African-American residents of the state experienced lynchings, such as two in 1902 and 1924 in Coos Bay, as well as routine threats of violence and harassment by Klu Klux Klan members in Salem and other cities. ${ }^{23}$ In the latter half of the 20th century the hegemony of whiteness has taken many forms, from the white supremacy movements that continued to flourish in Oregon and the Pacific northwest more generally, ${ }^{24}$ to the day-to-day assumptions that normalize white power and privilege in a state that in 1960 was 98 per cent white. The situation was amplified in the rural areas, where farmworkers labored and lived: in 1960 less than 1 per cent of the population of small towns in Oregon (with 2500-10,000 residents) was classified as 'nonwhite. ${ }^{25}$

Despite these broader patterns in Oregon, Woodburn nevertheless became a key destination for the incremental and permanent settlement of Mexican-American farmworkers in the state. The growth of Woodburn's Latino/a population is difficult to trace quantitatively since the census did not break down population by race at any scale until the 1980s. What the census does show is that compared with Oregon's other high farmworker-receiving counties, Marion County witnessed significantly more rapid growth in its Mexican-born population (Table 1). By 1980, when the census began to release data on race and ethnicity at the city scale, Woodburn had 1874 'Hispanic' residents, of a total population of 11,196 - a higher percentage than any other town or city in Marion County. My interviews with long-time Mexican-American residents of Woodburn indicate that most Latinos / as settling in Woodburn during the 1960s (and through the 1970s) were Mexican Americans who came from Texas or other parts of the U.S. Southwest. ${ }^{26}$ Comparatively fewer Mexican-born 
TABLE 1 Comparative Mexican-origin population in Oregon's top four farmworkerreceiving counties, Clackamas, Hood river, Marion and Wasco counties. U.S. Census data, $1960-2000$

\begin{tabular}{llllll}
\hline & 1960 & 1970 & 1980 & 1990 & 2000 \\
\hline Clackamas & 48 & 220 & 1,871 & 5,021 & 12,530 \\
Hood River & 9 & 98 & 951 & 2,559 & 4,570 \\
Marion & $\mathbf{4 4 3}$ & $\mathbf{1 , 8 1 0}$ & $\mathbf{7 , 8 1 7}$ & $\mathbf{1 5 , 7 3 7}$ & $\mathbf{4 1 , 2 1 9}$ \\
Wasco & 11 & 52 & 300 & 935 & 1,926 \\
\hline
\end{tabular}

farmworkers settled permanently during these early decades, an unsurprising situation given the barriers of language and legal status.

The growing resident Mexican-American population in Woodburn during the 1960s and 1970s created the seeds of activism and identity politics through which Latinos/as began to claim 'cultural citizenship.' According to William Flores, cultural citizenship 'names a range of social practices which, taken together, claim and establish a distinct social space for Latinos beyond the limits of legal status and the exclusions of dominant white society'. ${ }^{27}$ For example, in 1964 MexicanAmerican residents organized the first Fiesta Mexicana in Woodburn, including a parade and beauty pageant, a tradition that continues to this day. ${ }^{28}$ In 1969 the Centro Chicano Cultural of Woodburn purchased land on Highway 99 between Woodburn and Gervais for the construction of a cultural center. The center sought to create an ethnic library, organize public lectures, and publish a newsletter for the Chicano community. ${ }^{29}$ The early 1970s also witnessed the founding of the Valley Migrant League (VML) by Chicano activists, a service organization for migrant workers that provided bilingual services, created a healthcare clinic, and organized child care centers. ${ }^{30}$

Despite these important achievements, Mexican-born and Mexican-American residents of Woodburn nevertheless remained largely on the outside of local power structures through the 1980s and into the 1990s. Latinos/as represented nearly one-sixth of Woodburn's population in 1980, and one-third in 1990, yet dominant representations of Woodburn as a community normalized whiteness and constructed Latinos/as as 'other.' In 1989, for example, Woodburn celebrated the 100-year anniversary of the town's founding. The 'Centennial Program,' a 12-page history of Woodburn written for the event by the city-appointed Centennial Commission, focused almost exclusively on Woodburn's white pioneer history. Woodburn's Latino/a population was given a mere 65 words in a section tellingly entitled 'Hispanic Influx.' In contrast, three entire articles are devoted to the town's 'founding father' Jesse Settlemeier, recounting his arrival in a covered wagon and the obstacles he overcame to carve Woodburn out of a seemingly empty landscape. ${ }^{31}$ In addition to these representational practices, local political and economic power structures remained overwhelmingly white. For example, the first Latino/a city council person was not elected to the six-member city council until 1986.

Nonetheless, during the 1980 s the underlying economic context began to change in ways that undermined the normalized containment of farmworker social reproduction in isolated camps far from most white residents. Structural changes in the regional economy, coupled with broader shifts in labor flows between Mexico and the USA, rapidly increased the number of Mexican laborers arriving to work in the Northern Willamette Valley. In 1977, the USDA estimated that Oregon hired an average of 64,000 farmworkers per year, ${ }^{32}$ whereas by 
1992 that number had nearly doubled to $120,000 .{ }^{33}$ In addition to the increasing number of workers arriving in the region, the hiring season for farmworkers was lengthening during this period as agricultural production intensified and diversified. ${ }^{34}$ For example, labor-intensive nursery and greenhouse crop production expanded dramatically: in 1987 Marion County had 3.3 million square feet of covered nursery and greenhouse production, which grew to 11.1 million square feet by $1992 .{ }^{35}$ Nursery expansion, as well as the broader diversification of rural industries during that period, pulled more farmworkers to the region and made it possible for many to cobble together year-round employment and settle permanently in the Northern Willamette Valley.

Housing for farmworkers, however, did not respond quickly to these economic shifts. The labor camp, the classic and usually inhumane site of farmworker housing, was no longer feasible for workers who were staying permanently in the region. ${ }^{36}$ First, the ability to stay in a particular camp was frequently linked to employment with a particular grower, a situation that could not be sustained as longer seasons and year-round employment with multiple employers became more widespread. Second, unlike the lone male migrant farmworker of previous decades, the conditions in most labor camps were particularly difficult for families to negotiate. As a growing number of families arrived in the 1980 s they increasingly opted to look for in-town housing, despite the severe housing shortage ${ }^{37}$ Third, even as the demand for farmworkers was increasing in the 1980s, the number of labor camps was in decline throughout the state. ${ }^{38}$

As farmworkers sought out long-term housing in small and larger urban centers in the Northern Willamette Valley, they found a situation that was often dire. While labor camps were known for their deplorable conditions (see note 36), many farmworkers seeking shelter in town found themselves sleeping under bridges, in parks, or in their cars. As the Woodburn Independent reported, '[f]armworker families are living in cars, camping in city parks and piling into small houses and apartments because they cannot find affordable housing. ${ }^{39}$ During 1991 the Woodburn Independent ran 32 articles and/or op-eds addressing the farmworker housing crisis, and in its 1 January 1992 issue declared the farmworker housing crisis its number two story of 1991 (its number one story was the arrival of Wal-Mart to town).

It is in this context that FHDC was founded, and began its efforts to construct safe and decent 'urban' farmworker housing in the Northern Willamette Valley. Their efforts challenged the spatial politics of exclusion represented by the institution of the labor camp as well as the structural conditions that pushed a growing number of farmworkers to sleep under bridges and in their cars. Formally incorporated in early 1991, FHDC represented an extension of the politics and agendas of several long-standing farmworker and Latino/a advocacy organizations: Salud Medical Center, PCUN (Piñeros y Campesinos Unidos del Noroeste/Northwest Treeplanters and Farmworkers United), Legal Aid Services of Oregon Farmworker Program, and CASA of Oregon (a statewide farmworker housing organization based in Newberg). Despite feeling overwhelmed in the context of their own work, activists from these organizations devoted an enormous amount of time to founding FHDC, including developing a formal needs assessment, seeking out funding for housing development, and creating the institutional infrastructure necessary to ensure the fruition of their vision. Their vision included not only housing for farmworkers, but the creation of a space of empowerment, linking housing to an array of supports for farmworkers and their families - from 
childcare to English and computer classes. The name chosen for their first development, Nuevo Amanecer (New Dawn) reflected the breadth of their vision for social and political change.

\section{Defending whiteness: resistance to Nuevo Amanecer}

In March 1993, as construction of Nuevo Amanecer was underway, an anonymous letter was sent to the manager of a nearby apartment building, signed by 'Americans for the Last Crusade':

The Mexicans are going to have a housing project in Woodburn, right across the street from the high school where their gangs can freely mingle with our kids. If you don't think this housing project will create gangs just check with police agencies in Southern California. The Mexicans will work the summer season and then spend the winters in living quarters built for them with our money. They will create a bigger dope problem and crime will increase. [...] What our politicians (Governor Roberts and her gang) are creating will become a cesspool of humanity. ${ }^{40}$

This letter was not the first overtly racist message directed at farmworker housing advocates. The day before the groundbreaking ceremony for Nuevo Amanecer in December 1992, FHDC representatives found a spray-painted plywood sign set up at the Nuevo Amancer site reading: 'Future home of Salud's slum. ${ }^{41}$ The letter and the graffiti both mark Nuevo Amanecer as threatening, as a site of criminality and impurity due to the presence of racialized (and poor) others. It is a common trope implicated in the racialization of landscapes. ${ }^{42}$

Although such anonymous and overtly racist discourses are important to understanding geographies of whiteness and the racialization of difference, I am interested in closely analyzing more subtle narratives, articulated within public forums and not anonymous, that function to maintain spaces of normative whiteness. What narratives were explicitly invoked to resist the siting of Nuevo Amanecer? While the letter from 'Americans for the Last Crusade' indicates that explicitly racialized fear of criminality were lying just below the surface of this resistance, as I detail later the public discourse against Nuevo Amanecer was framed in terms of 'taxpayers rights.' The notion of 'taxpayer rights' does not have an immediately identifiable spatial dimension; nevertheless it functioned to defend white spatial privilege, particularly the right to control urban space, and exclude brown, low-wage and 'illegal' bodies from Woodburn.

The struggle over Nuevo Amanecer centered on the specific site chosen for the project and the city's efforts to prevent FHDC from purchasing it. While FHDC board minutes from 1991 indicate that a number of sites were considered, by fall of that year board members became very interested in purchasing a site in Woodburn called 'Grace Village.' A largely undeveloped 11-acre parcel, Grace Village represented an ideal property for Nuevo Amanecer because of its central location and already-developed sewer connections. It also happened to be owned by the City of Woodburn, and the city was trying, rather unsuccessfully, to find buyers for the site. $^{43}$

Grace Village was an unfinished retirement housing project partially funded in 1985 through a $\$ 245,000$ Housing and Urban Development (HUD) community development grant. ${ }^{44}$ Funneled through the Oregon Housing Agency but administered by the City of 
Woodburn, the grant was used by private developers who went bankrupt after building only three apartments on the site. The failure of the project left the City of Woodburn not only in default of the agreement between the city, the state of Oregon, and HUD, but liable for the grant money as well. In 1989 the city filed suit against the developers to recover its losses. Although the city gained title to Grace Village, it was unsuccessful in recouping the grant money. ${ }^{45}$ The city had few options. It could sell to private developers and use the proceeds to repay the HUD grant, or it could find another community development-eligible project for the site. FHDC's project not only fulfilled HUD community development grant objectives, but by early 1992 FHDC had the support of the Oregon Housing Agency, the Department of Economic Development, and Marion County to develop Nuevo Amanecer on the Grace Village site. It seemed like a 'win-win' situation, yet every time FHDC representatives contacted the city to set up a meeting to discuss the property they were either ignored or told to wait until a future, unspecified date. ${ }^{46}$

By the spring of 1992 stories about how to dispose of Grace Village began to appear with more regularity in the Woodburn Independent. Those articles, and letters to the editor responding to them, began to call for selling Grace Village to the 'highest bidder' in order to protect the city's 'taxpayers.' The argument that it should be sold to the highest bidder explicitly hinged on the idea that the disposition of the property should not only pay off the HUD grant, but fully cover the legal expenses the city had incurred taking the private developers of Grace Village to court. Farmworker housing was not mentioned explicitly in any of these discussions, but the framing of the issue can only be understood against the backdrop of FHDC's expressed interest in obtaining the property. In the minds of many residents and city council members these legal expenses would be 'lost' to taxpayers if the property was turned over to FHDC, despite the fact that FHDC had offered to pay the city's legal expenses to date if granted title to Grace Village. ${ }^{47}$ The subtext of repeated calls for the city to sell it to the 'highest bidder' was a code for not selling it to FHDC.

Passive and active resistance to the farmworker housing project came to a head in June 1992. Finding the city council unwilling to hear their proposal to buy the property, FHDC leaders 'jumped scale ${ }^{48}$ and asked their supporters within county and state agencies to leverage the community development grant debt to force the city to turn over the property. ${ }^{49}$ As a result of their efforts, on 19 June 1992 the City received a letter from the Oregon Economic Development Agency:

The state of Oregon directs the city to transfer the Grace Village property to Marion County within two weeks of the date of this letter. [...] once the city transfers the property to Marion County [...] the city will have no further liabilities or obligations to the state under the agreement and will be eligible for future CDBG (Community Development Block Grant) awards. ${ }^{50}$

Because Marion County (via Commissioner Mary Pearmine) had agreed to act as the local government partner for FHDC, turning the property over to the county essentially represented victory for FHDC. The state's directive left the city with few options, but local leaders continued to resist. On 22 June the council met and much of the day's agenda was consumed by a discussion of Grace Village. Despite the clear wording from the state of Oregon, the council moved to meet in executive session and consult their attorneys regarding their options to resist complying with the state order. 
It is useful to quote from this meeting at some length, as the public discourses circulating about Grace Village and farmworker housing were clearly articulated at the meeting. First, the mayor read a letter to the council signed by 46 residents and dated 16 June 1992:

The undersigned members of the community wish to commend you for getting the City Council back on track in the matter of the sale of Grace Village. It is our opinion that the City's official position, according to press accounts, has been that Grace Village Property will be sold to the highest bidder once the legal hurdles have been addressed. It seems to us to be counterproductive for the Council to either consider disposing of Grace Village property by any other means than the sale to the highest bidder after having spent two a half years and significant taxpayer funds positioning itself to accommodate such a sale. [...] It would be fiscally irresponsible for the council to entertain any other course of action. Please express to the council our concern for this matter. We believe the council should proceed with due diligence to dispose of Grace Village by sale to the highest bidder. ${ }^{51}$

This letter reflects the extent to which public opposition to Nuevo Amanecer was framed in terms of taxpayers expense and fiscal responsibility. Shortly after the 'citizens' letter was read publicly in front of the city council, Al Nuñez, president of FHDC's board of directors, spoke about his repeated yet unsuccessful efforts to meet with the city to discuss Grace Village and his frustration in that context:

[Our proposal] would give the city its out of pocket expenses for legal costs, $[\ldots]$ the city would no longer have the obligation nor be liable any longer to Grace Village. And you haven't listened to our proposal. [...] It is very unfortunate and I am really disappointed that we were just not allowed to make a proposal. We did a professional job. We have funding not only from state agencies, but we have guaranteed loans from commercial banks. [...] But we were not heard, we were not given an opportunity to make a presentation to you to approve or to deny, and that's unfortunate..$^{52}$

Shortly after Mr Nuñez' testimony, one council member expressed his idea of a solution to the problem:

I guess if worse comes to worse we owe the state $\$ 245,000$ and we don't own any property. We could dig up the $\$ 245,000$, give it back to the state and sell it to the highest bidder and make ourselves a tidy profit. That is a possibility also. The state doesn't own that property, we do. We owe them money but we own the property.

Not one of the other councilors challenged this statement or responded directly to $\mathrm{Mr}$ Nuñez' statement quoted above. Instead, the council debate centered on finding any 'solution' that would allow the city to avoid the directive sent from the Economic Development Department and thus prevent the construction of Nuevo Amanecer on the site.

It took the city council two more months of executive meetings and consultation with attorneys to finally see that there were no other options. On 27 August they authorized an agreement with the state of Oregon to dispose of the Grace Village property by turning it over to Marion County. The groundbreaking ceremony for Nuevo Amanecer on 11 December 1992 was attended by Governor Barbara Roberts, whose support had been crucial to overcoming local opposition. ${ }^{53}$ After an extended process getting the plans for Nuevo Amanecer approved by the city, and overcoming all financing and construction obstacles, phase I of Nuevo Amanecer was completed and ready for tenants on 14 August 1994. The design of the complex was dramatically different from classic farmworker housing: the apartments, two, three- and four-bedroom, had ground floor entries and vaulted ceilings. There was a laundry facility, community room and extensive greenspace and playground for children. Nuevo 
Amanecer created living space for farmworkers that contrasted sharply with the history of farmworker housing.

The fierce resistance to Nuevo Amanecer on the part of city leaders and a number of vocal and overwhelmingly white residents provides insight into normalized landscapes of whiteness 'threatened' by the settlement of Latino/a immigrant families. If the city had accepted FHDC's proposal from the outset, its debt to the Oregon Economic Development Agency would have been erased and (without much effort on their part) they would have taken a step towards alleviating Woodburn's highly visible housing crisis. In this context, their adamant refusal to turn over the property, or even listen to FHDC's proposal, was predicated on the assumption that farmworker housing did not belong in Woodburn. It was an assumption so deeply normalized it did not have to be verbalized at the city council meeting. ${ }^{54}$ Moreover, underlying this resistance was an implicit desire on the part of city council members not to appear complicit in the construction of state-subsidized farmworker housing that in many ways legitimized the presence of farmworkers in the community. ${ }^{55}$

The discourse of protecting 'taxpayers' and selling to the 'highest bidder' functioned to defend exclusions based on race, class, and legal status. It was an unsurprising choice given the readily available neoconservative discourses, on the rise during the 1980s, that constructed the poor, people of color and immigrants as undeserving of social services paid for by 'taxpayers'. ${ }^{56}$ 'Taxpayer' functioned in this case as a code for the 'real' (read 'white, legal and middle-class') citizens of Woodburn, since many assume that immigrant residents are 'illegal' and thus do not pay taxes. ${ }^{57}$ It is a racialized coding that relies not only on the assumed extra-legal position of immigrants residents (in which all brown people are assumed to be 'illegal'), but on their class position as well. ${ }^{58}$ The discourse of 'taxpayer's money' provided a legitimate and normalized narrative that could be deployed to exclude without the explicit mention of race, class, or legality.

\section{Defending whiteness: resistance to Esperanza Court}

In June 1995 FHDC purchased a vacant lot in the heart of downtown Woodburn, directly across from city hall (see map, Figure 2), in order to build Esperanza (Hope) Court. Similar in format and conception, but smaller than Nuevo Amanecer, this development would contain 12 units. By this time, 3 years after the heated struggles over Grace Village and Nuevo Amanecer, a different set of circumstances indicated that this project would perhaps face less resistance. First, by 1995 FHDC had a clear track record for its management of Nuevo Amanecer, which from the outset was a well-run facility recognized nationally for its design and its innovative participatory management structure. Second, Nuevo Amanecer had even become a point of pride in the community, as reflected in a front-page Woodburn Independent article in the fall of that year:

Woodburn's Nuevo Amanecer apartments hosted more than 100 delegates from the National Congress for Community Economic Development on Friday. Delegates were attending a national conference in Portland last week and came to Woodburn to see firsthand Woodburn's award-winning farmworker housing project. ${ }^{59}$

Despite these new circumstances, opposition to Esperanza Court was equally fierce. Opponents, however, had fewer tools with which to stop the project: by the time FHDC publicly announced their intentions, they already owned the lot. 
The announcement of FHDC's land purchase was greeted with shock and indignation on the part of many city leaders, who argued that they had long intended to buy the lot for a community center. ${ }^{60}$ Resistance to Esperanza Court developed on two fronts. First, the planning commission effectively slowed down the building permit process and second, the city council proposed a ballot initiative that would instruct the city to 'buy or condemn land near city hall for a new community center and other public facilities.' It was an initiative clearly directed at the FHDC lot since it was 'the only piece of vacant property in close proximity to city hall. ${ }^{61}$

The drawn-out permitting process created a series of public hearings where arguments for and against Esperanza Court could be publicly articulated. The level of public debate was one of the key differences between the struggle over Esperanza Court as compared with Nuevo Amanecer. Various meetings of the planning commission and the city council were devoted to the issue in 1996, and rather than having a handful of people in the room as in the case of discussions over Nuevo Amanecer, these meetings were packed with people for and against the project.

FHDC submitted a site plan to the planning commission in December 1995, but did not receive a final approval from that commission until August 1996. A planner who worked with FHDC to obtain planning commission approval for the plan, Greg Winter, recounted the extensive delays to the approval process in testimony to the city council:

[In March 1996] I was asked [by FHDC] to work with your planning staff about what was needed for compliance and we went over each and every standard in your zoning code. We received three or four letters back about what was missing [from our design]. I met with the staff at the end of March and we went over each point in your zoning code. We made substantial changes, including moving the building to the front of the lot and adding a tot lot. We submitted the revised application in April 1996. I found the application to be extremely complete. The staff did not find it complete enough. The staff has not given us any breaks in this application. The outstanding issue was the size of a parking space. The code requires 9 by 19 feet. In my 28 year experience of planning that is interpreted to allow part of that [measurement] to include overhang on the curb. But we changed the site plan to show a full 19 feet. Not bringing it up to disparage planning staff, but we have been over every code. ${ }^{62}$

The city planning commission seemed bent on finding any planning code that could slow down their approval of the project. On 8 August 1996 the commission delayed approval for the project because Esperanza Court had only one loading zone, and regulations required two. Although one commissioner wanted to reject the project entirely for this fault, the vote was delayed instead. Clearly concern about regulatory details was not the heart of this resistance. At that meeting one commission member and a former mayor of Woodburn both urged the commission to reject the project because 'Woodburn already has too much farmworker housing. ${ }^{63}$ The same article quoted another commissioner as stating 'I looked hard to find a way to vote against this [...] but there is no legal way I can do it.'

After many delays, by fall it appeared that every building and design code that possibly could apply to Esperanza Court had been reviewed and the plan revised accordingly. On 26 August 1996 the planning commission unanimously approved the site plan for Esperanza Court, with two abstentions. Several commissioners told a Woodburn Independent reporter that they voted reluctantly to approve the project but did so because that is what the 'city planner instructed them to do. ${ }^{64}$ The meeting was filled with people rallied by FHDC and sister organizations in Woodburn, as well as a few opponents. As supporters gathered outside to 
cheer after the vote, the Woodburn Independent reported that things 'turned ugly when opponents started a shouting match.' According to the newspaper story, a white resident 'told the mostly Hispanic crowd to 'go home.' The crowd, clearly agitated, responded by shouting 'we are home!'?65

In spite of the planning commission's approval, the city council delayed final city approval for the project until they could hold a public hearing on the matter in October 1996. According to one person who served on the city council at the time, councilors were aware that they were on shaky legal ground if they wanted to deny the plan because the land was zoned for multi-family housing. However, according to this ex-councilor it was politically important for the city council to weigh in on the issue, to 'take a stand. ${ }^{.66}$

The meeting opened with the Mayor of Woodburn, Nancy Kirksy, recusing herself as mayor because she wanted to testify 'as a citizen' in opposition to Esperanza Court. Shortly thereafter the head city planner discussed the planning approval process, describing in detail the planning regulations guiding the final Esperanza Court design. He ended by telling the council that FHDC had complied with every regulation, and that since the housing complex was an outright permitted use on the site the planning commission had approved the project. His statement was followed by letters and testimony from supporters of Esperanza Court, including leaders of organizations from Woodburn, Salem and Portland, white and MexicanAmerican residents of Woodburn, and farmworkers themselves, both documented and undocumented. ${ }^{67}$ The depth and breadth of their testimony articulated an important counter-narrative to the hegemony of whiteness in Woodburn, making a spatial claim to citizenship and belonging in the town. One female farmworker (age approximately 28) testified:

I am Hispanic and I work in the field. Before coming to Nuevo Amanecer I used to live with my two children on a farm. It was difficult to live there, there were about 30 men living there. I couldn't do anything in private. I was always very nervous. I looked for an apartment, but it was difficult. I work in strawberries, blackberries, cucumbers. I didn't have a fixed job. I could not find an apartment for that reason. I know that there are a lot of people in the same situation, please support this project. ${ }^{68}$

As represented by this women's testimony, the city council hearing on Esperanza Court provided undocumented farmworkers a unique opportunity to tell their stories to state officials and to 'legal' residents of the community. In that moment they enacted citizenship and belonging in ways rarely afforded undocumented residents. White officials and 'legal' residents were in the usual position of having to listen to these stories and provide space for their narration. In writing about developing alternative pedagogies that deconstruct whiteness Peake and Ray write:

How do we $[. .$.$] bring into view the exclusions, erasures and unevenness that characterize the landscape forma-$ tion processes of whiteness? [...] Encounters are the moments when realities of domination and oppression become embodied, but they are simultaneously opportunities to disrupt meta-narratives. ${ }^{69}$

The notion of 'encounter' and the disruption of meta-narratives is a valuable analytical tool for understanding the significance of moments such as this hearing in which farmworkers, normally excluded and invisible within the public sphere, have the opportunity to tell their story publicly.

Most relevant to the argument put forth in this article, however, are the discourses deployed to resist the construction of Esperanza Court. Most of the opponents who testified did not 
explicitly contest the need for farmworker housing in the abstract, but they often framed their opposition in terms of its location - farmworker housing just did not 'belong' in downtown Woodburn. One white man, in his early 70 s testified,

I have lived in downtown 30 years. Lots of change. My heart goes out to the people that spoke tonight. Honestly, we do need more farmworker housing. I am not against that, I am against the location. If something could be worked out ... I am against multiple family residents in the downtown area. I have seen the city hall being built, library ... farmhousing downtown is not in conjunction with this plan. The people of Woodburn, we screwed up. We should have bought this land a long time ago. But it is not too late. ${ }^{70}$

These sentiments were echoed by a subsequent speaker, a white member of the planning commission in his late 50s:

I am on the planning commission, but speaking as a private citizen. I feel that other uses are more appropriate for downtown, it is a step backwards, I agree with the previous speaker. I was totally for Nuevo Amanecer, I was on the planning commission I think it is a lovely development, we do have a need for farmworker housing. This is the wrong location. ${ }^{71}$

For them, the centrally located lot should be used for other uses (such as a community center or parking lot) despite zoning designations that allowed multi-family dwellings.

Another testimony, from a white woman in her mid-60s, also draws on the idea that farmworker housing does not belong, but her speech more explicitly invokes a racialized and classbased sense of loss over downtown:

The City's policy for encouraging downtown as a hub has sparked my objection to the farmworker housing project. It cannot attract the private investment needed to create a downtown. Downtown Woodburn is shabby. Buildings, streets, and sidewalks are need a lot of attention. Private capital is needed to revitalize downtown. The city can contribute as well, capital to create public buildings and services. What we need downtown is not more low income housing, we have enough of that. What we need downtown is a transit center, railroad station, community center, retail centers, performing arts centers, and more parking. The city's investment in a community center will trigger private investment. This kind of investment will make downtown again the hub of the city. $^{72}$

Her description of downtown Woodburn as 'shabby' was loaded given that by the mid-1990s new downtown businesses were largely owned by Mexican immigrants and Mexican Americans. Spanish was becoming the lingua-franca on the streets of downtown Woodburn. Her comments, although explicitly directed at Esperanza Court, contain deeper anxiety about downtown Woodburn as a space of racialized difference. She contests claims to the city being made by Mexican immigrants, arguing Esperanza Court is not necessary because 'we already have enough' low-income housing.

From a legal perspective, the passionate speeches denouncing the approval of a farmworker housing project in downtown Woodburn were undertaken in vain. The city attorney told the city council at the hearing that they could not deny the plan for Esperanza Court based on the idea that it was not an 'appropriate' use of the site. According to Oregon State law, and the U.S. Fair Housing Act, the only criteria for denial would be the zoning rules and building codes. Since FHDC was in compliance with all of those rules, any decision except approval would be overturned in court. At the end of the 3-hour hearing, the majority of councilors voted to sustain the planning commission's approval of the project, although the 
mayor did not vote because she had stepped down to testify against the project, and one councilor abstained from voting. As the abstaining councilor remarked,

\footnotetext{
During this process I have felt there should be a latitude for the Council in its deliberations, taking into account any developing trend that harm the city of Woodburn. It seemed to me if this wasn't the case, that the only use of the council was to check the land use laws and rubber stamp the Planning Commission. It seems that we are in that position ... I do not resent the planning commission, they were doing their job, I blame the dictatorial powers of the state as these laws were written.
}

It seemed to me that our responsibility was to serve the voting public and to favorably effect the outcome of this city. My fight has been to avoid the deterioration of our property values, and by improper or thoughtless planning. In this case I cannot vote my conscious, so I will abstain from voting on this issue. ${ }^{73}$

While directly alleviating the housing crisis, farmworker housing is constructed in this passage as harming Woodburn. The nature of what kind of harm is unclear, except for the vague reference to 'our' property values - a claim harkening back to justifications for red lining practices. Moreover, the collectivity invoked by 'our' is clearly white and middle-class.

The struggle over Esperanza Court, like that over Nuevo Amanecer, brought out competing visions of place, race and belonging in Woodburn during a period of rapid demographic change. While the racial anxieties linked to the permanent settlement of low-wage immigrant workers had percolated for many years, the discussions about the city turning over Grace Village to FHDC in 1991 and the hearings over approving Esperanza Court's building permit in 1996 created sites for public debates over the presence of farmworker families living in Woodburn. In these forums, the resistance to these farmworker housing projects depended, I argue, upon unspoken assumptions about the spatiality of whiteness and difference. In the case of Nuevo Amanecer, narratives of protecting 'taxpayers' functioned as a code for the protection of white residents by treating them as potential 'victims' of the proposed project. Taxpayer narratives mobilized to prevent the city from turning Grace Village over to FHDC were predicated on the assumption that farmworkers did not belong in town an assumption that never had to be spoken because the city owned the property and assumed such ownership implied control over the decision. The debate over Esperanza Court was more explicitly spatial: although the speakers at the 1996 hearings did not articulate where they thought farmworker families and housing belonged, perhaps they were harkening back to a time when the spaces of farmworker social reproduction was more fully contained within labor camps - beyond urban boundaries and out of sight.

\section{Epilogue}

Two recent moments connected to Woodburn highlight the ever-shifting configurations of race across time and space. First, on 25 September 2005 the town inaugurated the first major project of its downtown urban renewal initiative: a Latin-American-styled plaza in the heart of downtown. The creation of the 'Downtown Plaza' as it is called indicates a shift in the spatialities of whiteness and difference in the community, as well as the growing power of Latinos. From the vigorous attempts to prevent the construction of farmworker housing in the early 1990s, by the end of that decade a growing number of (still mostly white) city leaders began 
to embrace Woodburn's 'Mexican' identity - at least for commercial and practical purposes. ${ }^{74}$ One white resident who had been on the city council during the mid-1990s (and from that position vigorously opposed Esperanza Court) led an initiative in 1998 for the creation of the urban renewal district and the plaza project. Not the only indicator of change, in 2002 the city hired a Latino 'community relations officer' to organize community activities, such as a city-sponsored celebration of Mexican Independence Day and a regular Spanish-language film series. ${ }^{75}$

This is not to claim that racism has disappeared from Woodburn - far from it. The political and economic power structures remain overwhelmingly white and several white residents I interviewed $(n=7)$ expressed open frustration with the presence of 'the Mexicans.' A second Latino resident joined the city council briefly in 2002, but left office by 2004 due to a change in residency. This leaves the city council with only one Latino representative despite Latinos/as representing a majority of city residents. ${ }^{76}$ Moreover, my interviews with immigrant and Mexican-American residents included frequent reference to day-to-day experiences of racism. But constructions of place and the public sphere in Woodburn have become decidedly more pluralistic, partly I think as a result of struggles such as those over Nuevo Amanecer and Esperanza Court.

Second, one day before the inauguration of Woodburn's plaza an article about Woodburn was published in the living section of the Oregonian newspaper (based out of Portland):

\footnotetext{
Woodburn has become downright famous as home to Oregon's largest outlet mall. But if you're seeking a subtler treat, turn your car east at the Interstate 5 overpass and spend and afternoon in the other Woodburn. [...] Most of the signs are in Spanish, but don't let that intimidate you as you enter the color-splashed, six block grid affectionately known as 'Little Mexico.' ${ }^{77}$
}

In discussing the 'space that race makes,' David Delaney points out the importance of scale in 'inscribing or effacing difference. ${ }^{78}$ In this text from the Oregonian, produced at the scale of the state rather than the city, Woodburn is coded as other and exoticized as (white) Oregon's space of difference. Oregonian identity can 'safely' remain white if Latino difference (the most rapidly growing ethnic 'minority' in the state) can be coded and contained in the town of Woodburn.

Reading these two brief examples against the stories of Nuevo Amanecer and Esperanza Court helps demonstrate the instability and contestability of race and space. On the one hand, as seen through the Downtown Plaza, less than a decade after the heated debates over Esperanza Court new configurations of power, and a different racialization of space, has emerged in Woodburn. On the other hand, as seen through the Oregonian, racialized spaces are being imagined differently from another scale. Rather than seeing these changes as natural or teleological, it is crucial to see them as a result of social and political struggle that will continue to transform cultural and political landscapes in Oregon and elsewhere.

\section{Acknowledgements}

I would like to thank the Farmworker Housing Development Corporation for their support for this research, particularly Roberto Franco, Laura Isiordia, Carmen Ramírez, and Roberto Jiménez. A special thank you to Alberto Nuñez, Ramón Ramírez and Larry Kleinman for their help and for their many years dedicated to advocating on behalf of farmworkers in the Northern Willamette Valley. I am also deeploy grateful for the feedback from Andrew Schulz, Joseph Nevins, Monica Varsanyi, Alec Murphy, 
and Susan Hardwick, and the anonymous reviewers. All errors or unconvincing interpretations are my own. This research was supported by two Summer Research Awards from the University of Oregon.

\section{Biographical note}

Lise Nelson is an Assistant Professor at the University of Oregon, USA. Her research examines the ways in which neoliberal globalization is transforming social identities, understandings of place and belonging, as well as governance practices in Mexico and the United States. Her recent publications include 'Geographies of state power, protest, and women's political identity formation in Michoacán, Mexico' in the Annals of the Association of American Geographers and 'Artesanía, mobility and the crafting of indigenous identities among Purhépechan women in Mexico' in the Journal of Latin American Geography. She can be contacted at: Department of Geography, University of Oregon, Condon 100, Eugene, OR 97403-1251, USA; email: lise@uoregon.edu

\section{Notes}

1 G. Lipsitz, The possessive investment in whiteness: how white people profit from identity politics (Philadelphia, Temple University Press, 1998), p. 1.

2 A. Bonnett, 'Whiteness studies: the problems and projects of a new research agenda', Theory, culture and society 13 (1996), pp. 145-55; R. Dyer, White: essays on race and culture (London, Routledge, 1997); R. Frankenberg, 'Growing up white: feminism, racism and the social geography of childhood', Feminist review 45 (1993), pp. 51-84.

3 A. Kobayashi and L. Peake, 'Racism out of place: thoughts on whiteness and an antiracist geography in the new millennium', Annals of the Association of American Geographers 90 (2000), pp. 392-403.

4 For explorations of whiteness by geographers see A. Amin, 'Ethnicity and the multicultural city: living with diversity', Environment and planning A 34 (2002), pp. 959-80; L. Peake and B. Ray, 'Racializing the Canadian landscape: whiteness, uneven geographies and social justice', Canadian geographer 45 (2001), pp. 180-6; P. Jackson, 'Constructions of "whiteness" in the geographical imagination', Area 30 (1998), pp. 99-106; M. McGuinness, 'Geography matters? Whiteness and contemporary geography', Area 32 (2000), pp. 225-30; J. S. Duncan and N. G. Duncan, Landscapes of privilege: the politics of aesthetic in an American suburb (New York, Routledge, 2004); L. Pulido, 'Rethinking environmental racism: white privilege and urban development in southern California', Annals of the Association of American Geographers 90 (2000), pp. 12-40.

5 M. Omi and H. Winant, Racial formation in the United States from the 1960s to the 1980s (New York, Routledge, 1986).

6 W. Doane, 'Rethinking whiteness studies', in A. W. Doane and E. Bonilla-Silva, eds, White out: the continuing significance of racism (New York, Routledge, 2003).

7 D. Delaney, 'The space that race makes', The professional geographer 54 (2002), pp. 6-14.

8 P. Jackson, 'Geography, 'race' and racism', in R. Peet and N. Thrift, eds, New models in geography: the political-economy perspective (Boston, Unwin-Hyman, 1989).

9 Duncan and Duncan, Landscapes of privilege: the politics of aesthetic in an American suburb.

10 Pulido, 'Rethinking environmental racism: white privilege and urban development in southern California'.

11 On parallel processes in California, see E. M. Allensworth and R. I. Rochín, The Mexicanization of rural California: a socio-demographic analysis 1980-1997 (East Lansing, Julian Samora Research Institute, 1999); S. Chávez, 'Community, ethnicity, and class in a changing rural Californian town', Rural sociology 70 (2005), pp. 314-35. 
12 See U.S. Census (Washington, DC, U.S. Census Bureau, 2000). This contrasts significantly with the fact that in 1980, 16 per cent of the population identified as 'Hispanic,' see U.S. Census (Washington, DC, U.S. Census Bureau, 1980). I do not mean to imply that all immigrants are farmworkers, as many have transitioned into low-wage service work. Nevertheless, 'farmwork' defined broadly to include agricultural processing, treeplanting, and work on farms clearly has been driving this demographic shift.

13 FHDC, Farmworker housing needs assessment and recommendations for Woodburn, Oregon (Woodburn, 1991), p. 12.

14 T. Henderson, 'Landlords told to fix complex', Woodburn independent, (6 February 1991), p. 2.

15 Sanchéz, Ursula (pseudonym) Mexican-born farmworker age 32, undocumented, interviewed 15 December 2004.

16 N. DeBuse, 'Governor to speak at comeback event', Woodburn independent, (13 March 1991), p. 1.

17 Between 2003 and 2005 I conducted 27 interviews in Woodburn, which included farmworkers (all of whom where born in Mexico), Mexican-American residents, white residents, city employees, excity councilors and an ex-mayor of the city. I also conducted participant observation of tenant meetings for Nuevo Amanecer and Esperanza Court (11 meetings total), as well as of community celebrations in Woodburn (i.e. Founder's Day 2004, Mexican Independence Day celebrations in 2003). In addition, I reviewed, and engaged in textual analysis of, Woodburn independent articles from 1968 to 1998 , planning documents relevant to farmworker housing issues, city council hearing transcripts, and FHDC board minutes from 1991 to 1997.

18 E. Gamboa, Mexican labor \& World War II: Braceros in the Pacific northwest, 1942-1947 (Seattle, University of Washington Press, 2000).

19 Unlike official bracero workers, Mexican-American farmworkers did not have a federal agency mediating their relationship with employers; they were 'free' wage earners and thus represented a more attractive workforce. These farmworkers, from Texas to California, were willing to migrate to the Pacific northwest because wages were comparatively higher - wages in the southwest were depressed due to the continued reliance on bracero workers from Mexico. See Gamboa, 'Mexican labor \& World War II'.

20 In this article I use the category of Latino/a to denote a group that includes both Mexican immigrants (as well as the very small percentage of immigrants from other Latin American countries in Woodburn) and Mexican Americans. The use of this category allows me to name a process that places all brown bodies in a racialized category, irrespective of legal status or class. I use it cautiously and recognize the risk of creating a monolithic category that functions to reinscribe racial hierarchies.

21 D. Mitchell, The lie of the land: migrant workers and the California landscape (Minneapolis, University of Minnesota Press, 1996), p. 199.

22 R. Keith, 'Unwelcome settlers: black and mulatto Oregon pioneers part I', Oregon historical quarterly 84 (1983), pp. 29-55.

23 E. McLagan, A peculiar paradise: A bistory of blacks in Oregon, 1788-1940 (Portland, Georgian Press, 1980).

24 E. V. Toy, Jr, 'The Klu Klux Klan in Tillamook, Oregon', Pacific northwest quarterly 53 (1962), pp. 60-4; Organized white supremacists in Oregon: a report (Portland, Coalition for Human Dignity, 1990).

25 U.S. Census (Washington, DC, U.S. Census Bureau, 1960).

26 See also E. Flores, 'Festejando community: celebrating fiesta Mexicana in Woodburn, Oregon', in R. M. De Anda, ed., Chicanas and Chicanos in contemporary society (Lanham, Rowman \& Littlefield, 2004).

27 W. V. Flores and R. Benmayor, Latino cultural citizenship: claiming identity, space, and rights (Boston, Beacon Press, 1997), p. 1.

28 Flores, 'Festejando community'.

29 'Chicanos purchase land south of city', Woodburn independent (9 October 1969), p. 1.

30 'VML clinic underway', Woodburn independent (10 October 1973), p. 3.

31 Woodburn Centennial Commission, Woodburn centennial program (Woodburn, Oregon, 1989). There is also no mention of Native Americans living in the Willamette Valley upon the arrival of white settlers. 
32 Crop Reporting Board, Farm labor (Washington, DC, U.S. Department of Agriculture, 1980).

33 U.S. Census of agriculture (Washington, DC, USDA National Agricultural Statistics Service, 1992).

34 R. Mason, Farm labor demand for six Oregon crops (Corvallis, Agricultural Experiment Station, Oregon State University, 1989).

35 U.S. Census of agriculture (Washington, DC, USDA National Agricultural Statistics Service, 1992). The demand for rural, low-wage workers was not confined to agriculture. Timber corporations began to lower their costs of production by replacing white treeplanting crews with subcontracted groups of Mexican and Mexican-American workers, see G. Mackie 'The rise and fall of the forest workers' cooperatives of the Pacific northwest', MSc thesis, University of Oregon, Eugene, (1990).

36 A 1982 study indicated that only 25 per cent of labor camps in Oregon were code-compliant: 'problems include poor quality water, hazardous electrical service, unsanitary toilet facilities, inadequate hot water, sewage backflow in drain fields adjacent to housing facilities, garbage overflow and some incidence of overcrowding' Report on rural housing (Salem, Oregon Rural Housing Coalition, 1982). A 1986 Oregon Bureau of Labor and Industries report documented substandard farmworker housing conditions in communities across the state, see The dilemma of farmworker housing: an issue of statewide concern in Oregon (Salem, Oregon Bureau of Labor and Industries, 1986). In addition to the often degrading conditions inside the camps, workers living in isolated areas have little access to basic services and are less able to contest unfair labor practices or unhealthy working conditions. For an overview of farmworker housing conditions in the USA, see C. Holden, 'Bitter harvest: housing conditions of migrant and seasonal farmworkers', in C. D. Thompson and M. F. Wiggins, eds, The buman cost of food: farmworkers' lives, labor and advocacy (Austin, University of Texas Press, 2002); Findings from the national agricultural workers survey (NAWS) 1997-1998: A demographic and employment profile of United States farmworkers (Washington, DC, Office of the U.S. Department of Labor, Office of Program Economics, 2000).

By the mid-1980s Mexican immigrants throughout the USA were settling with their families rather than migrating as single men, see K. M. Donato, J. Durand and D. Massey, 'Stemming the tide? Assessing the deterrent effects of the immigration reform and control act', Demography 29 (1992), pp. 139-57. Particularly after the 1986 Immigration Reform and Control Act, which provided amnesty for 2.3 million undocumented workers, a growing number of farmworkers were in a position of sponsoring their families to join them, see S. G. Baker, 'The 'amnesty' aftermath: current policy issues stemming from the legalization programs of the 1986 immigration reform and control act', International Migration Review 31 (1997), pp. 5-27.

38 Report of special seasonal farmworker housing task force (Salem, Marion County Board of Commissioners, 1988).

39 N. Debuse, 'Racism issues aired', Woodburn independent, (6 March 1991), pp. 1-2.

40 G. Rede, 'Wooburn police investigate anti-Hispanic letter', The Oregonian, (19 March 1993), p. 5.

41 Alberto José Nuñez (not a pseudonym by request), founding member and president of the board of directors between 1991 and 1995, FHDC, interviewed 15 August 2005.

Duncan and Duncan, Landscapes of privilege: the politics of aesthetic in an American suburb, p. 185.

N. Debuse, No takers for Grace Village', Woodburn independent, (13 March 1991), p. 1.

The project was eligible for a HUD grant because it fit national community development objectives by creating thirty new jobs, 51 per cent of which would be filled by lower to moderate income persons.

45 N. Debuse, 'Hud sides with plaza del sol', Woodburn independent, (11 October 1991), pp. 1-2.

46 Efforts to contact city officials to discuss Grace Village were mentioned at FHDC board meetings 14 January, 11 February, and 10 March 1992. The board minutes from 11 February, for example, noted that 'The mayor did not want $\mathrm{Al}$ to make any presentation at this time to the Council members.' At this same meeting FHDC representatives started actively discussing how to ask county and state officials to 'pressure' the city to listen to 'our proposal.' 
47 By early 1992 FHDC had received sufficient loan guarantees and public grants for the project that they could cover the cost of paying the city's legal expenses (FHDC board minutes 1991-1992).

48 See L. Staeheli, 'Empowering political struggle: spaces and scales of resistance', Political geography 13 (1994), pp. 387-91; W. Van Schendel, 'Geographies of knowing, geographies of ignorance: jumping scale in Southeast Asia', Environment and planning D: society and space 20 (2002), pp. 647-68; B. A. Miller, Geography and social movements: comparing antinuclear activism in the Boston area (Minneapolis, University of Minnesota Press, 2000).

49 FHDC, Board meeting minutes (Woodburn, OR, 1992).

50 City of Woodburn, tape of city council meeting 22 June 1992. Transcribed by author.

51 Ibid.

52 Ibid.

53 L. Hamnik, 'Governor pays visit to Nuevo Amanecer site', Woodburn independent (16 December 1992), pp. 1-2.

54 It also did not need to be explicitly articulated at the meeting because the city owned the property and thus resistance to farmworker housing could be framed in other readily-available terms.

55 In other words, the hegemony of whiteness in Woodburn at the time made it politically impossible for city council members to vote to turn over Grace Village to FHDC even if that vote would have erased a $\$ 245,000$ debt. This interpretation of the council's protracted and determined resistance is reflected in a comment shared with me by a white resident, born in Woodburn, who described her frustration over the farmworker housing project: 'my daughter, who lives in Portland, does not get the government to make her rent cheaper' - Eleonore Zuckerman (pseudonym) white resident of Woodburn for over 40 years, age 63, interviewed 25 August 2003.

56 Z. Eisenstein, 'Privatizing the state: reproductive rights, affirmative action, and the problem of democracy', Frontiers: a journal of women studies 12 (1991), pp. 98-125.

57 On taxes and immigrants see D. Schneider, 'Symbolic citizenship, nationalism and the distant state: the United States congress in the 1996 debate on immigration reform', Citizenship studies 4 (2000), pp. 255-73.

58 S. Morgen and J. Maskovsky, "The anthropology of welfare "reform": new perspectives on U.S. Urban poverty in the post-welfare era', Annual review of anthropology 32 (2003), pp. 315-38.

59 N. Debuse, 'National convention tours Woodburn's Nuevo Amanecer apartments', Woodburn independent (10 July 1995), p. 1.

60 The claim that the city had long intended to buy the lot was articulated at the 15 October 1996 city council meeting devoted to a debate over the building permit for Esperanza Court. It was a sentiment confirmed in an interview with a ex-city councilor in office during this period, interviewed 10 August 2005.

61 Both quotations are from P. Johnson, 'Ballot seeks advice on property', Woodburn independent (21 August 1996), p. 1. It is difficult to tell how seriously staff and council members wanted that vacant lot prior to FHDC's purchase, or whether it was a narrative created afterwards to justify resistance to Esperanza Court.

62 City of Woodburn, videotape of city council meeting 15 October 1996.

63 P. Johnson, 'Farmworker apartments hit snag', Woodburn independent (14 August 1996), pp. 1-2.

64 P. Johnson, 'Council will review planners' decision on FHDC project', Woodburn independent (28 August 1996), pp. 1-2.

65 Ibid., p. 1.

66 Ex-city councilor (white), in office during 1995 hearings over Esperanza Court, interviewed 10 August 2005.

${ }^{67}$ As indicated by the group of people who mobilized in support of Esperanza Court, the categories of 'white' and 'Latino' do not map neatly onto a pro- or anti-Esperanze Court division, serving as a reminder that in this analysis 'white' is a discursive category within political discourse and practice. 
One Mexican-American resident of Woodburn testified at the meeting against Esperanza Court, for example. Nevertheless, all the white people testifying in support of Esperanza Court were from out of town (usually Salem or Portland) and the vast majority of Latinos who testified supported Esperanze Court.

68 City of Woodburn, videotape of city council meeting on 15 October 1996.

69 Peake and Ray, 'Racializing the canadian landscape: whiteness, uneven geographies and social justice', p. 184.

70 City of Woodburn, videotape of city council meeting on 15 October 1996.

71 Ibid.

72 Ibid.

73 Ibid.

74 One prominent white business leader explained to me how beneficial it had been for his business to offer services catering to Spanish-speaking clientele, a policy that began in earnest in 2000 . He explained that he became involved in cross-cultural community activities (boards of directors, etc.) when he realized that 'Mexicans' were key clients for his business, interviewed 20 May 2003.

75 The community relations coordinator also produces a quarterly bilingual newsletter.

76 Of course this is partly a result of the high percentage of immigrants who are not documented, however I do not think that fully explains the discrepancy.

77 G. Wozniacka, 'An echo of Mexico in Woodburn', Oregonian (24 September 2005), p. C1.

78 Delaney, 'The space that race makes', p. 7. 